\title{
An Investigation into the Teachers' Use of L1 in EFL Classes
}

\section{OPEN ACCESS}

Volume: 9

Special Issue: 2

Month: September

Year: 2021

E-ISSN: 2582-1334

Received: 25.07.2021

Accepted: 28.08.2021

Published: 15.09.2021

Citation:

Tanriseven, Ufuk, and Yasemin Kırkgöz. "An Investigation into the Teachers' Use of L1 in EFL Classes." Shanlax International Journal of Education, vol. 9, no. S2, 2021, pp. 125-31.

DOI:

https://doi.org/10.34293/ education.v9iS2-Sep.4377

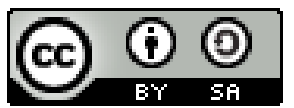

This work is licensed under a Creative Commons Attribution-ShareAlike 4.0 International License

\section{Ufuk Tanriseven}

Beyza College, Turkey

https://orcid.org/0000-0002-2786-7988

\section{Yasemin Kırkgöz}

Çukurova University, Turkey

https://orcid.org/0000-0001-5838-6637

\begin{abstract}
In many countries where English is used as a second or foreign language (ESL/EFL), the classroom is the main context for students' exposure to the target language (L2); however, English teachers have a tendency to use the mother tongue (L1) excessively. As a result, the appropriate use of L1 in language classrooms remains as a major problem. This study investigates Turkish EFL teachers' perspectives on the use of L1, and functions that the teachers' use of L1 serves in foreign language classrooms. Mixed method research design was adopted using a questionnaire and semistructured interviews. English teachers $(n=43)$ responded to the Use of L1 Questionnaire and semistructured interviews were held with eight volunteer teachers working in Beyza private schools in a province in Turkey. Quantitative data from the Likert scale questionnaire items was analysed using descriptive statistics to reveal frequency, mean and standard deviation scores, and inductive content analysis was applied for the analysis of qualitative data. The findings have demonstrated that most teachers avoid or limit the use of L1 systematically and give priority to using L2 in EFL classrooms. Findings also suggest that L1 can be used as a facilitating tool for explaining difficult grammar and vocabulary items, managing classrooms, giving instructions, checking for comprehension and establishing a friendly classroom environment.
\end{abstract}

Keywords: The mother tongue (L1), The target language (L2), Monolingual view

\section{Introduction}

English functions as the global language of business, science, trade and academic research (Graddol, 2006). The world-wide importance of English has played a significant role on the educational policy in many countries; as a result, governments have introduced English early in their school curricula in order to enhance the communicative competence of the students. In the development of students' communicative competence, the use of the mother tongue (L1) can be a beneficial tool in foreign language classes provided the teachers are aware of its use effectively. Teachers are generally recommended to resort to L1 to facilitate students' learning of English in a stress-free classroom environment (Brooks-Lewis, 2009). Therefore, abolishing the use of L1 appears to be futile since the use of L1 serves many functions in learning the target language (L2) in contexts where English is learned as a second or foreign language (ESL/ EFL).

\section{Theoretical Framework}

The debate about the use of L1 in teaching ESL/EFL settings is dominated by two major lines of thought; the monolingual principle and the line of thought which takes an opposite view and sees a pedagogical value in using L1 for language instruction. 


\section{The Monolingual View to Language Instruction}

The monolingual view or the L2-only language instruction holds the idea that using L1 would minimize the exposure to L2. The supporters of the monolingual view argue that using L1 in the classroom would be counterproductive and limit input and learners' production of L2 (McMillan \& Rivers, 2011); therefore, language teachers and learners should be discouraged from using LI in ESL/EFL classroom activities. Phillipson (1992) views this perspective as the 'monolingual fallacy', which maintains that language is best taught in a monolingual environment.

\section{The View Supporting the Use of L1 in Language Instruction}

The second line of thought to foreign language teaching takes an opposite view and considers a pedagogical value in using $\mathrm{L} 1$. The proponents of this view argue that the extensive use of L2 could be harmful to learners' cognitive and affective developments; instead L1 can be employed as a beneficial tool to support the development of the L2 learner for linguistic, cognitive development as well as for affective reasons (Atkinson, 1993; BrooksLewis, 2009; Butzkamm, 2003; Cummins, 2007; Macaro, 2001; Phillipson, 1992; Qian, Tian,\& Wang, 2009). Turnbull (2001) claims that using L1 can save time in the ESL/EFL classrooms, in situations when students have difficulties in understanding a difficult grammar concept or vocabulary. It is also argued that (Butzkamm \& Caldwell, 2009; Macaro, 2001) some cautions should be taken when L1 is used, and the amount of using L2 should be at a maximum level.

To sum up, the overall perspective seems to be that the optimal and judicious use of L1 can have a facilitating function in learning the target language. This view of using L1 adequately runs contrary to the arguments of those scholars who strongly believe in the monolingual approach and support the Englishonly instruction principle.

\section{Relevant Literature}

Kim and Petraki (2009) studied teachers' perceptions towards using L1 in a Korean school in Vietnam. Teachers expressed a positive view about using L1 and they reported to use L1 in English classes to explain the meaning of new words and expressions, manage the lessons, and explain grammar rules. Similarly, Yao (2011) reports that teachers hold positive opinions about switching to L1 in language classrooms.

In the Turkish context, Şenel (2010) reports that teachers use L1 to check for comprehension, explain the meanings of new vocabulary, and clarify the meaning of complex language items. Using 15 audiorecorded lessons, and semi-structured interviews with the teachers, Sali (2014) examined teachers' perspectives of using L1 and the functions for which L1 is used in three secondary school classrooms in Turkey. Three functional categories were identified: the academic, managerial, and social/cultural categories.

Qian, Tian, and Wang (2009) investigated Chinese primary school teachers' use of L1 in a Chinese primary school. It was found that teachers used L1 to give clear instructions and elicit responses from students. Investigating five secondary school English teachers working in Turkish public schools, Kirkgöz (2018) found that teachers use L1 mostly for giving instructions, classroom management, explaining aspects of the English language, and establishing rapport. Teachers believed that English should be the main medium of communication; yet, they highlighted that the use of Turkish can serve as a pedagogical tool when needed.

\section{Research Questions}

The research questions of the present study are

1. To investigate the Turkish EFL teachers' perceptions about the use of L1 in foreign language classrooms.

2. To reveal the functions that the teachers' use of L1 serves in foreign language classrooms.

\section{Research Methodology}

This study used a mixed method research design that combines qualitative and quantitative research approaches in data collection and data analysis to obtain an in-depth understanding of the research topic. The findings of quantitative data were related systematically and coherently with qualitative data to address the research questions. 


\section{Participants}

The participants were 42 English teachers working in Beyza private schools in central Maraşprovince in Turkey. In the selection of the participants purposeful sampling (Creswell, 2014) was used due to the easy accessibility and proximity of the schools to the first researcher who was involved in the data collection process.

\section{Research Instruments Questionnaire}

The first research instrument was the Use of L1 Questionnaire which was specifically developed for the present study. The questionnaire items were adapted from the studies that were closely related to the objectives of the present study (Sali, 2011; Kırkgöz, 2018). The questionnaire consisted of demographic Information, a 15-item 5-point Likert Scale that aimed to investigate the teachers' level of agreement to the use of L1 in the language classrooms. Finally, teachers' opinion on the use of L1 was elicited through five open-ended questions. The questionnaire was piloted, and Cronbach's Alpha value was found to be 859 , which shows that the adapted questionnaire is reliable and valid to be used in the actual study.

\section{Interviews}

Semi-structured interviews were administered to eight volunteered teachers who also responded to the questionnaire. Interviews were conducted face to face and in English, they were audiorecorded, and later transcribed for data analysis. Ten interview questions were prepared to obtain in-depth information about the teachers' opinions on the use of L1 and the reasons for using it in language classes, and the collection of the data took place during the 2019-2020 academic year.

\section{Data Analysis}

To describe the demographic information of the participants, frequencies were calculated. Descriptive statistics such as mean and standard deviation scores were used for the Likert scale questionnaire items in order to identify teachers' perceptions of using L1, and the functions that the teachers' use of L1 serves. The findings were presented in Tables. Next, qualitative data wereanalyzed using inductive content analysis, in which themes and categories emerging from the data were identified using the constant comparison method. The findings were categorized under themes, they were interpreted and presented by relevant excerpts. To preserve anonymity, the participants were represented with different codes such as 'P1' (Participant 1) and 'P2' (Participant 2).

The interview data were initially analyzed by the first researcher. The second researcher analyzed a small portion of the interview data for inter-rater reliability. To ensure intra-rater reliability, the researcher reviewed the whole interview data after a certain time had passed from the initial analysis. In light of all these, all of the categories were checked again and finalized.

\section{Results and Analysis}

The first part of the questionnaire explores the participants' demographic information, years of teaching experience, and the grade they teach. The information in Table 1 shows that the distribution of female (f: 21) and male participants (f:21) is equal in number. Most of the participants are at the age of either 25-30 (f: 20) or 31-35 (f: 14). Similarly, most participants (f:17) have 6-10 years of experience, followed by $1-5$ years of experience (f:16). Clearly, most of the participants (f:25) teach in secondary schools, 6 participants teach both primary and secondary school students, and one participant is observed to teach only primary school students.

Table 1: Demographic Information about Participants

\begin{tabular}{|l|l|c|}
\hline \multicolumn{2}{|c|}{ Variables } & f \\
\hline \multirow{4}{*}{ Gender } & Female & 21 \\
\cline { 2 - 3 } & Male & 21 \\
\hline \multirow{4}{*}{ Age range } & $25-30$ & 20 \\
\cline { 2 - 3 } & $31-35$ & 14 \\
\cline { 2 - 3 } & $36-40$ & 7 \\
\cline { 2 - 3 } Year of experience & $41-45$ & 1 \\
\hline & $1-5$ & 16 \\
\cline { 2 - 3 } & $6-10$ & 17 \\
\cline { 2 - 3 } & $11-15$ & 5 \\
\cline { 2 - 3 } & $16-20$ & 4 \\
\hline
\end{tabular}




\begin{tabular}{|l|l|c|}
\hline \multirow{3}{*}{ Grade taught } & Primary & 1 \\
\cline { 2 - 3 } & Secondary & 25 \\
\cline { 2 - 3 } & Both & 16 \\
\hline
\end{tabular}

Moving on to the second part of the questionnaire, which investigated the Turkish EFL teachers' perspectives on the use of L1 in language classrooms, the results of quantitative data from the 15 -item Likert scale questionnaire are presented in 4 sections. Table 2 presents the teachers' general opinion regarding the use of $\mathrm{L} 1$, as represented by Items 1, 2, 3, and 6 .

Table 2: Participants' General Perspectives Regarding the Use of $\mathrm{L1}$

\begin{tabular}{|l|c|c|}
\hline \multicolumn{1}{|c|}{ Items } & Mean & SD \\
\hline $\begin{array}{l}\text { 1. Turkish should be used in } \\
\text { English classes. }\end{array}$ & 2.86 & 1.39 \\
\hline $\begin{array}{l}\text { 2. Use of Turkish prevents students } \\
\text { from learning English. }\end{array}$ & 3.50 & 1.53 \\
\hline $\begin{array}{l}\text { 3. Use of Turkish in the classroom } \\
\text { helps students to learn English } \\
\text { more effectively. }\end{array}$ & 2.95 & 1.58 \\
\hline $\begin{array}{l}\text { 6. Students should be permitted to } \\
\text { use Turkish in pair/group activities } \\
\text { to communicate efficiently. }\end{array}$ & 2.73 & 1.45 \\
\hline
\end{tabular}

As evidenced from Table 2, teachers unanimously agreed to Item 1, which is about "use of Turkish prevents students from learning English" with a high mean value (X:3.50). They moderately agreed to Item 3 related to the "use of Turkish in the classroom helps students to learn English more effectively" (X: 2.95); next to Item 1 "Turkish should be used in English classes" (X: 2.86), and finally Item 6 "students should be permitted to use Turkish in pair/group activities to communicate efficiently" (X: 2.73).

Using the functional categories of Sali (2014), the remaining questionnaire items are grouped under academic, managerial and social/affective functional categories. Academic functions, comprising Items $4,7,11,12$ in the questionnaire, are about how the subject of the lesson is communicated in L1.
Table 3: Academic Functional Categories

\begin{tabular}{|l|c|c|}
\hline \multicolumn{1}{|c|}{ Items } & Mean & SD \\
\hline $\begin{array}{l}\text { 4. Students can understand English } \\
\text { grammar better when explained in } \\
\text { Turkish. }\end{array}$ & 3.55 & 1.64 \\
\hline $\begin{array}{l}\text { 7. Teachers should use Turkish to } \\
\text { explain difficult vocabulary. }\end{array}$ & 3.50 & 1.63 \\
\hline $\begin{array}{l}\text { 11. Use of Turkish helps the teacher } \\
\text { to review the previously learned } \\
\text { subject. }\end{array}$ & 3.04 & 1.27 \\
\hline $\begin{array}{l}\text { 12. Use of Turkish helps the teacher } \\
\text { check comprehension. }\end{array}$ & 2.93 & 1.37 \\
\hline
\end{tabular}

As demonstrated by Table 3, teachers agreed most to Item 4 "students can understand English grammar better when explained in Turkish" with the highest mean (X:3.55); followed by Item 7 stating that "teachers should use Turkish to explain difficult vocabulary" (X:3.50), next to Item 11 "use of Turkish helps the teacher to review the previously learned subject" (X:3.04), and finally they moderately believed that "use of Turkish helps the teacher check comprehension (X:2.93), as stated by Item 12 .

Managerial functions focus on managing the lesson and the student behavior (Sali, 2014). Three statements (Items $8,13,14$ ) on the questionnaire investigate teachers' perspectives of using L1 regarding managerial functions.

Table 4: Managerial Functional Categories

\begin{tabular}{|l|c|c|}
\hline \multicolumn{1}{|c|}{ Items } & Mean & SD \\
\hline $\begin{array}{l}\text { 8. Use of Turkish helps students } \\
\text { understand the teacher's } \\
\text { instructions more easily. }\end{array}$ & 3.21 & 1.58 \\
\hline $\begin{array}{l}\text { 13. Use of Turkish helps the } \\
\text { teacher to organize the classroom } \\
\text { better. }\end{array}$ & 2.90 & 1.36 \\
\hline $\begin{array}{l}\text { 14. Use of Turkish helps the } \\
\text { teacher to correct student errors. }\end{array}$ & 3.04 & 1.34 \\
\hline
\end{tabular}

According to Table 4, teachers' agreement was highest to Item 8 stating that "use of Turkish helps students understand the teacher's instructions more easily (X: 3.21 ), followed by Item 14, which indicated that "use of Turkish helps the teacher to correct student errors" with mean value (X: 3.04), and finally teachers moderately believed that "use of 
Turkish helps the teacher to organize the classroom better" (X: 2.90), as stated by Item 13 in the questionnaire.

The final functional category was social/ affective corresponding to Items 9,10 , and 15 on the questionnaire. The results are displayed in Table 5.

\section{Table 5: Social/Affective Functional Categories}

\begin{tabular}{|l|c|c|}
\hline \multicolumn{1}{|c|}{ Items } & Mean & SD \\
\hline $\begin{array}{l}\text { 9. Use of Turkish helps establish a } \\
\text { better relationship with the teacher. }\end{array}$ & 3.36 & 1.68 \\
\hline $\begin{array}{l}\text { 10. Use of Turkish lowers students' } \\
\text { stress and anxiety. }\end{array}$ & 3.69 & 1.84 \\
\hline $\begin{array}{l}\text { 15. Use of Turkish helps the teacher } \\
\text { to give opinions. }\end{array}$ & 3.09 & 1.36 \\
\hline
\end{tabular}

As seen in Table 5, teachers mostly agreed that "Use of Turkish lowers students' stress and anxiety" with a high mean score (X: 3.69), next to Item 9 "Use of Turkish helps establish a better relationship with the teacher" (X: 3.36), and finally the participants' level of agreement was found to be rather high to Item 15 "Use of Turkish helps the teacher to give opinions" (X: 3.09).

Analyses of the qualitative data showed that most teachers agreed with the "only English" principle due to a number of reasons. They believed that using L2 creates an authentic learning environment, as expressed by a participant (P39) "Using English is the only way to create the real English learning atmosphere". Some participants (P34, P36) stated that "Using different approaches in the classroom helps students, especially young learners, to concentrate on the lesson." It was thought that English should be used in lessons as much as possible and the use of L1 should be restricted to emergency situations.

The remaining teachers expressed a preference for L2 use; however, they acknowledged that there are moments when they resort to L1 to support student learning. According to one participant (P1), English teachers may sometimes need to code switch to L1 to explain complex grammar items, teach vocabulary, clarify instructions, and manage especially young learner classes, more effectively. Taking a similar view, another participant reported that "There can bemoments when we need to use L1." (P12). These participants proposed that L2 can be learned more effectively through maximum exposure to the target language, and the use of L1 must be avoided as much as possible not to overshadow students' exposure to L2.

Regarding the second research question which explored what functions the teachers' use of L1 serve in English classrooms, comments provided by the teachers were classified into six categories: to explain difficult grammar, practice vocabulary and enhance pronunciation, check comprehension, give instruction, maintain discipline, and make students feel comfortable.

Participants resorted to L1 when they encountered problems in explaining difficult language items. One participant (P5) used L1 when teaching grammar items such as the present perfect. In teaching vocabulary, many participants used L1 as the last resort "I first teach the new words using English and body language. If it does not help, I give the Turkish meaning." (P22). The same participant illustrated that when the subject may cause anxiety for the student, she feels the need to translate some keywords into Turkish to make students understand the topic better.

Regarding giving instructions, the participants used L1 if instructions have not been understood by students. Furthermore, participants used L1 to initiate the lesson, maintain discipline, and capture students' attention. One participant (P25) highlighted that "When there is misbehavior in the classroom, I use Turkish."

The final category for using L1 was related to "making students feel comfortable". Some participants believed that the occasional use of L1 creates a break from the extensive exposure to L2, helping them to build rapport with students, and avoid boredom. Although participants accepted that they used L1 in case of an emergency, there was a general agreement among them for using it judiciously and purposefully.

\section{Discussion and Conclusion}

The study investigated Turkish EFL teachers' perspectives about the use of L1 (Turkish) in EFL classes and identified the functions for which L1 is used by the teachers in Beyza private schools in a province in Turkey. The findings of the study suggested that participants tended to limit the use 
of L1, and recognized the need for L1 use when needed. In this respect, teachers' opinion aligns with the argument proposed by scholars (Atkinson, 1993; Phillipson, 1992; Macaro, 2001) who noted that teachers can useL1 judiciously.

Regarding the functions that the teachers' use of L1 serves in English classrooms, the findings of the present study illustrate teachers' agreement on giving priority to the use of L2. However, findings also suggest that L1 can be used as a facilitating tool in EFL classrooms in times of emergency for functions such as explaining grammar and vocabulary, giving instructions, managing lessons, checking for comprehension, and establishing a friendly classroom environment. These findings are similarly reported in the previous studies such as Kim and Petraki (2009), Şenel (2010), Qian et al., (2009), and Yao (2011). In addition, Kırkgöz (2018) identified the most common functions for using L1 as giving instructions, classroom management, explaining aspects of the English language, and establishing rapport and to limited extent comprehension checks and monitoring. Also, teachers' preference to useL1 for academic, managerial, and social/affective functions is similar to a study conducted by Sali (2014).

Finally, participants in this study believed that L1 use could support L2 learning; yet, they strongly cautioned that L1 should not be used excessively. It can thus be suggested that using the mother tongue in ESL/EFL classrooms can be a useful pedagogical resource.

\section{Implications for Further Research}

The study offers useful information and guidelines for teacher educators, practicing teachers, teacher trainers, and foreign language curriculum designers with regard to using L1 in ESL/EFL classes. Teacher educators can give prospective teachers specific guidance as to when the use of L1 may be beneficial and when it should be avoided. Similarly, practicing teachers can be guided to take advantage of their existing L1 judiciously rather than excessively. Curriculum designers can specify the amount of L1 that could be acceptable in language classes, and give teachers strict guidelines on when to avoid using it.
This article has been produced from the Master thesis of the first author.

\section{References}

Atkinson, David. Teaching Monolingual Classes. Longman, 1993.

Brooks-Lewis, Kimberly Anne. "Adult Learners' Perceptions of the Incorporation of their L1 in Foreign Language Teaching and Learning." Applied Linguistics, vol. 30, no. 2, 2009, pp. 216-235.

Butzkamm, Wolfgang. "We Only Learn Language Once. The Role of the Mother Tongue in Fl Classrooms: Death of a Dogma." Language Learning Journal, vol. 28, 2003, pp. 29-39.

Butzkamm, Wolfgangand, and John A.W. Caldwell. The Bilingual Reform: A Paradigm Shift in Foreign Language Teaching, Narr Dr. Gunter, 2009.

Creswell, John W. Research Design: Qualitative, Quantitative, and Mixed Methods Approaches. Sage, 2014.

Cummins, Jim. "Rethinking Monolingual Instructional Strategies in Multilingual Classrooms." Canadian Journal of Applied Linguistics, vol. 10, no. 2, 2007, pp. 221-240. Graddol, David. Why Global English May Mean the End of 'English as a Foreign Language, British Council, 2006.

Kim, Yuri, and Eleni Petraki. "Students' and Teachers' Use of and Attitudes to L1 in the EFL Classrooms."Asian EFL Journal, vol. 11, no. 4, 2009, pp.58-89.

Kırkgöz, Yasemin. "English Teachers' Uses of First Language in Turkey." Insider Accounts of Classroom Life Secondary Education, edited by Dantas-Whitney, and S. Rilling, TESOL, 2017, pp 101-106.

Macaro, Ernesto. “Analyzing Student Teachers' Code-switching in Foreign Language Classrooms: Theories and Decision Making." Modern Language Journal, vol. 85, no. 4, 2001, pp. 531-548.

McMillan, Brian. A., and Damian J Rivers. "The Practice of Policy: Teacher Attitudes toward English Only." System, vol. 39, no. 2, 2011, pp. 251-263. 
Phillipson, Robert. Linguistic Imperialism, Oxford, Tanrıseven, Ufuk. Investigating the Teachers' of L1 1992. in EFL Classes. Çağ University, 2020.

Qian, X., et al. "Codeswitching in the Primary EFL Turnbull, Miles. "There is a Role for the L1 in Classroom in China - Two Case Studies." Second and Foreign Teaching, But ...." System, vol. 37, no. 4, 2009, pp. 719-730.

Sali, Pinar. "An Analysis of the Teachers' Use of L1 The Canadian Modern Language Review, vol. 57, no. 4, 2001, pp. 531-538.

in Turkish EFL Classrooms." System, vol. 42, Yao, Mingfa. "On Attitudes to Teachers' Code2014, pp. 308-318.

Şenel, Müfit. "Should Foreign Language Teaching switching in EFL Classes." World Journal be Supported by Mother Tongue?." Journal of English Language, vol. 1, no. 1, 2011, pp. of Language and Linguistic Studies, 19-28. vol. 6, no. 1, 2010, pp. 110-120.

\section{Author Details}

Ufuk Tanriseven, Beyza College, Turkey,Email ID: tseven@gmail.com.

Prof. Dr. Yasemin Kırkgöz, Çukurova University,Turkey,Email ID: ykirkgoz@gmail.com. 